\title{
Donghicola eburneus gen. nov., sp. nov., isolated from seawater of the East Sea in Korea
}

\author{
Jung-Hoon Yoon, So-Jung Kang and Tae-Kwang Oh \\ Korea Research Institute of Bioscience and Biotechnology (KRIBB), PO Box 115, Yusong, \\ Taejon, Korea
}

Correspondence

Jung-Hoon Yoon

jhyoon@kribb.re.kr

\begin{abstract}
A Gram-negative, aerobic, slightly halophilic, non-motile and coccoid- or rod-shaped bacterial strain, SW-277 ${ }^{\top}$, was isolated from seawater, Korea, and subjected to a polyphasic taxonomic study. Strain SW-277 ${ }^{\top}$ was catalase- and oxidase-positive and grew optimally at $\mathrm{pH} 7.0-8.0$ and $37{ }^{\circ} \mathrm{C}$ in the presence of $2 \%(\mathrm{w} / \mathrm{v}) \mathrm{NaCl}$. Phylogenetic analysis based on 16S rRNA gene

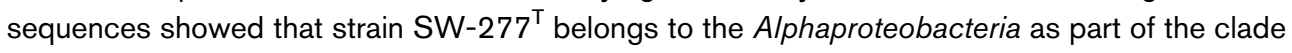
comprising the genera Roseivivax and Salipiger with a bootstrap resampling value of $72.5 \%$. $16 \mathrm{~S}$ rRNA gene sequence similarity values between strain $S W-277^{\top}$ and members of the genera Roseivivax and Salipiger were between 93.8 and $94.7 \%$. Strain SW-277 ${ }^{\top}$ contained Q-10 as the predominant ubiquinone and $\mathrm{C}_{18: 1} \omega 7 \mathrm{c}$ and $\mathrm{C}_{16: 0}$ as the major fatty acids. The DNA $\mathrm{G}+\mathrm{C}$ content was 59.7 mol\%. Strain SW-277 ${ }^{\top}$ could be distinguished from members of the phylogenetically related genera Salipiger and Roseivivax by phenotypic differences and low 16S rRNA gene similarity values. On the basis of phenotypic, chemotaxonomic, genotypic and phylogenetic data, strain SW-277 ${ }^{\top}\left(=\right.$ KCTC $\left.12735^{\top}=J C M 13604^{\top}\right)$ should be classified as a representative of a novel species in a new genus, Donghicola eburneus gen. nov., sp. nov.
\end{abstract}

In the course of screening novel micro-organisms from seawater of the East Sea, Korea, many moderately halophilic or halotolerant bacteria have been isolated and characterized taxonomically (Yoon et al., 2003b, 2004a, b, c). This study is focused on one of these isolates, $\mathrm{SW}-277^{\mathrm{T}}$. Comparative $16 \mathrm{~S}$ rRNA gene sequence analysis indicated that strain SW $-277^{\mathrm{T}}$ forms an independent branch within the Alphaproteobacteria. Accordingly, the aim of the present work was to determine the exact taxonomic position of strain SW $-277^{\mathrm{T}}$ by a polyphasic characterization that included phenotypic and chemotaxonomic properties and detailed phylogenetic analysis based on 16S rRNA gene sequences.

Strain SW $-277^{\mathrm{T}}$ was isolated by the standard dilution plating technique at $25^{\circ} \mathrm{C}$ on marine agar 2216 (MA; Difco). The morphological, physiological and biochemical characteristics of strain SW-277 ${ }^{\mathrm{T}}$ were investigated using routine cultivation on $\mathrm{MA}$ at $37^{\circ} \mathrm{C}$. Cell morphology and the presence of flagella were examined by light microscopy (Nikon E600; see Supplementary Fig. S1 in IJSEM Online) and transmission electron microscopy. For transmission electron microscopic observation, cells were negatively stained with $1 \%(\mathrm{w} / \mathrm{v})$ phosphotungstic acid and the grids were examined after air-drying with a Philips CM-20

The GenBank/EMBL/DDBJ accession number for the 16S rRNA gene sequence of strain SW- $277^{\top}$ is DQ667965.

A light micrograph of Donghicola eburneus gen. nov., sp. nov. strain SW$277^{\top}$ is available as supplementary data in IJSEM Online. transmission electron microscope. Growth under anaerobic conditions was determined after incubation in a Forma anaerobic chamber on MA and MA supplemented with nitrate, both of which had been prepared anaerobically using nitrogen. Growth in the absence of $\mathrm{NaCl}$ was investigated using trypticase soy broth prepared according to the formula of the Difco medium except that no $\mathrm{NaCl}$ was used. Growth at various $\mathrm{NaCl}$ concentrations $(0.5 \%$ and $1.0-15.0 \%, \mathrm{w} / \mathrm{v}$, at intervals of $1.0 \%$ ) was investigated in marine broth 2216 (MB; Difco) or trypticase soy broth (Difco). Growth at various temperatures $\left(4-45^{\circ} \mathrm{C}\right)$ was measured on MA. Catalase and oxidase activities and hydrolysis of casein, starch and Tweens 20, 40, 60 and 80 were determined as described by Cowan \& Steel (1965) using MA as base medium. Hydrolysis of hypoxanthine, tyrosine and xanthine was tested on MA using the substrate concentrations described by Cowan \& Steel (1965). Hydrolysis of aesculin, gelatin and urea, and nitrate reduction were investigated as described previously (Lanyi, 1987) with a modification that artificial seawater was used for preparation of media. The artificial seawater contained (per 1 distilled water) $23.6 \mathrm{~g} \mathrm{NaCl}, 0.64 \mathrm{~g} \mathrm{KCl}, 4.53 \mathrm{~g} \mathrm{MgCl}_{2} .6 \mathrm{H}_{2} \mathrm{O}$, $5.94 \mathrm{~g} \mathrm{MgSO}_{4} .7 \mathrm{H}_{2} \mathrm{O}$ and $1.3 \mathrm{~g} \mathrm{CaCl}_{2} .2 \mathrm{H}_{2} \mathrm{O}$ (Bruns et al., 2001). $\mathrm{H}_{2} \mathrm{~S}$ production was tested as described previously (Bruns et al., 2001). For in vivo pigment-absorption spectrum analysis, two strains were cultivated aerobically in the dark at $37^{\circ} \mathrm{C}$ in $\mathrm{MB}$ and liquid Erythromicrobium/ Roseococcus medium (Yurkov et al., 1994; DSMZ medium no. 767) with the modification that D-glucose was used 
instead of acetate. The cultures were washed twice by centrifugation using a MOPS buffer $(\mathrm{MOPS} / \mathrm{NaOH}, 0.01 \mathrm{M}$; $\mathrm{KCl}, 0.1 \mathrm{M} ; \mathrm{MgCl}_{2}, 0.001 \mathrm{M}$; pH 7.5) and disrupted by sonication with a Branson Sonifier 450. After removal of cell debris by centrifugation, the absorption spectrum of the supernatant was examined on a Beckman Coulter DU800 spectrophotometer. Susceptibility to antibiotics was detected on MA plates using antibiotic discs with the following concentrations: polymyxin B, $100 \mathrm{U}$; streptomycin, $50 \mu \mathrm{g}$; penicillin G, $20 \mathrm{U}$; chloramphenicol, $100 \mu \mathrm{g}$; ampicillin, $10 \mu \mathrm{g}$; cephalothin, $30 \mu \mathrm{g}$; gentamicin, $30 \mu \mathrm{g}$; novobiocin, $5 \mu \mathrm{g}$; tetracycline, $30 \mu \mathrm{g}$; carbenicillin, $100 \mu \mathrm{g}$; kanamycin, $30 \mu \mathrm{g}$; lincomycin, $15 \mu \mathrm{g}$; neomycin, $30 \mu \mathrm{g}$; and oleandomycin, $15 \mu \mathrm{g}$. Acid production from carbohydrates was determined as described by Leifson (1963) in open tubes. Utilization of substrates as sole carbon and energy sources was tested according to the method of Baumann \& Baumann (1981) using supplementation with $2 \%(\mathrm{v} / \mathrm{v})$ Hutner's mineral base (Cohen-Bazire et al., 1957) and $1 \%$ (v/v) vitamin solution (Staley, 1968). Other physiological and biochemical tests were performed with the API 20E and API ZYM systems (bioMérieux) according to the manufacturer's instructions.

Cell biomass for respiratory lipoquinone analysis and DNA extraction was obtained from cells that were cultivated for 2 days in $\mathrm{MB}$ at $37^{\circ} \mathrm{C}$. Chromosomal DNA was isolated and purified according to the method described by Yoon et al. (1996), with the exception that RNase T1 was used in combination with RNase A to minimize contamination of RNA. The 16S rRNA gene was amplified by PCR using two universal primers as described previously (Yoon et al., 1998). Sequencing of the amplified 16S rRNA gene and phylogenetic analysis were performed as described by Yoon et al. (2003a). Respiratory lipoquinones were analysed as described by Komagata \& Suzuki (1987) using reversedphase HPLC. For cellular fatty acid analysis, cell mass of strain $\mathrm{SW}-277^{\mathrm{T}}$ was harvested from MA plates after cultivation for 3 days at $37^{\circ} \mathrm{C}$. The fatty acids were extracted and fatty acid methyl esters were prepared according to the standard protocol of the MIDI/Hewlett Packard Microbial Identification System (Sasser, 1990). The DNA G+C content was determined by the method of Tamaoka \& Komagata (1984) with the modification that DNA was hydrolysed and the resultant nucleotides were analysed by reversed-phase HPLC.

Morphological, cultural, physiological and biochemical characteristics of strain $\mathrm{SW}-277^{\mathrm{T}}$ are given in the genus and species descriptions (see later) or are shown in Table 1. The almost complete 16S rRNA gene sequence of strain SW$277^{\mathrm{T}}$ determined in this study comprised $1416 \mathrm{nt}$, representing approximately $96 \%$ of the Escherichia coli $16 \mathrm{~S}$ rRNA gene sequence. In the phylogenetic tree based on the neighbour-joining algorithm, strain $\mathrm{SW}-277^{\mathrm{T}}$ joined the clade comprising two Roseivivax species and Salipiger mucosus of the Alphaproteobacteria with a bootstrap resampling value of $72.5 \%$ (Fig. 1). This tree topology
Table 1. Differential characteristics of Donghicola eburneus gen. nov., sp. nov. and related taxa

Species: 1, Donghicola eburneus gen. nov., sp. nov.; 2, S. mucosus (data from Martínez-Cánovas et al., 2004); 3, R. halodurans (data from Suzuki et al., 1999); 4, R. halotolerans (data from Suzuki et al., 1999). ND, Not determined. All species are positive for catalase, oxidase and susceptibility to chloramphenicol and streptomycin (not determined for S. mucosus). All species are negative for anaerobic growth, Voges-Proskauer test, hydrolysis of starch and susceptibility to tetracycline (not determined for S. mucosus).

\begin{tabular}{|c|c|c|c|c|}
\hline Characteristic & 1 & 2 & 3 & 4 \\
\hline Cell morphology & Cocci or rods & Rods & Rods & Rods \\
\hline Motility & - & - & + & + \\
\hline Pigment & - & - & Pink & Pink \\
\hline Bacteriochlorophyll $a$ & - & - & + & + \\
\hline $\mathrm{Na}^{+}$requirement & + & + & - & - \\
\hline Nitrate to nitrite & + & - & + & + \\
\hline ONPG reaction & - & - & + & + \\
\hline Indole production & - & - & + & + \\
\hline \multicolumn{5}{|l|}{ Hydrolysis of: } \\
\hline Gelatin & - & - & - & + \\
\hline Tween 80 & + & - & - & - \\
\hline Urea & - & + & - & - \\
\hline \multicolumn{5}{|l|}{ Acid production from: } \\
\hline L-Arabinose & + & ND & + & - \\
\hline D-Cellobiose & + & - & $\mathrm{ND}$ & ND \\
\hline D-Fructose & + & - & + & + \\
\hline D-Galactose & + & - & + & - \\
\hline D-Glucose & + & - & + & + \\
\hline Lactose & + & - & + & - \\
\hline Maltose & + & - & + & - \\
\hline D-Mannose & + & - & $\mathrm{ND}$ & ND \\
\hline D-Ribose & - & $\mathrm{ND}$ & + & - \\
\hline Sucrose & + & - & + & - \\
\hline D-Xylose & - & $\mathrm{ND}$ & - & + \\
\hline D-Mannitol & + & - & $\mathrm{ND}$ & ND \\
\hline D-Sorbitol & + & - & ND & ND \\
\hline \multicolumn{5}{|l|}{ Utilization of: } \\
\hline L-Arabinose & + & - & $\mathrm{ND}$ & ND \\
\hline D-Glucose & + & - & + & + \\
\hline D-Fructose & + & - & $\mathrm{ND}$ & ND \\
\hline D-Galactose & + & - & $\mathrm{ND}$ & ND \\
\hline D-Cellobiose & + & - & ND & ND \\
\hline D-Mannose & + & - & $\mathrm{ND}$ & ND \\
\hline Acetate & + & - & + & + \\
\hline Citrate & - & - & + & + \\
\hline Succinate & + & - & + & + \\
\hline L-Glutamate & - & $\mathrm{ND}$ & + & + \\
\hline \multicolumn{5}{|l|}{ Susceptibility to: } \\
\hline Penicillin & + & ND & - & - \\
\hline Polymyxin B & + & - & ND & ND \\
\hline DNA G $+C$ content $(\mathrm{mol} \%)$ & 59.7 & 64.5 & 64.4 & 59.7 \\
\hline
\end{tabular}

was found in trees generated with the maximum-likelihood and maximum-parsimony algorithms. Strain SW- $277^{\mathrm{T}}$ exhibited 16S rRNA gene sequence similarity values of 


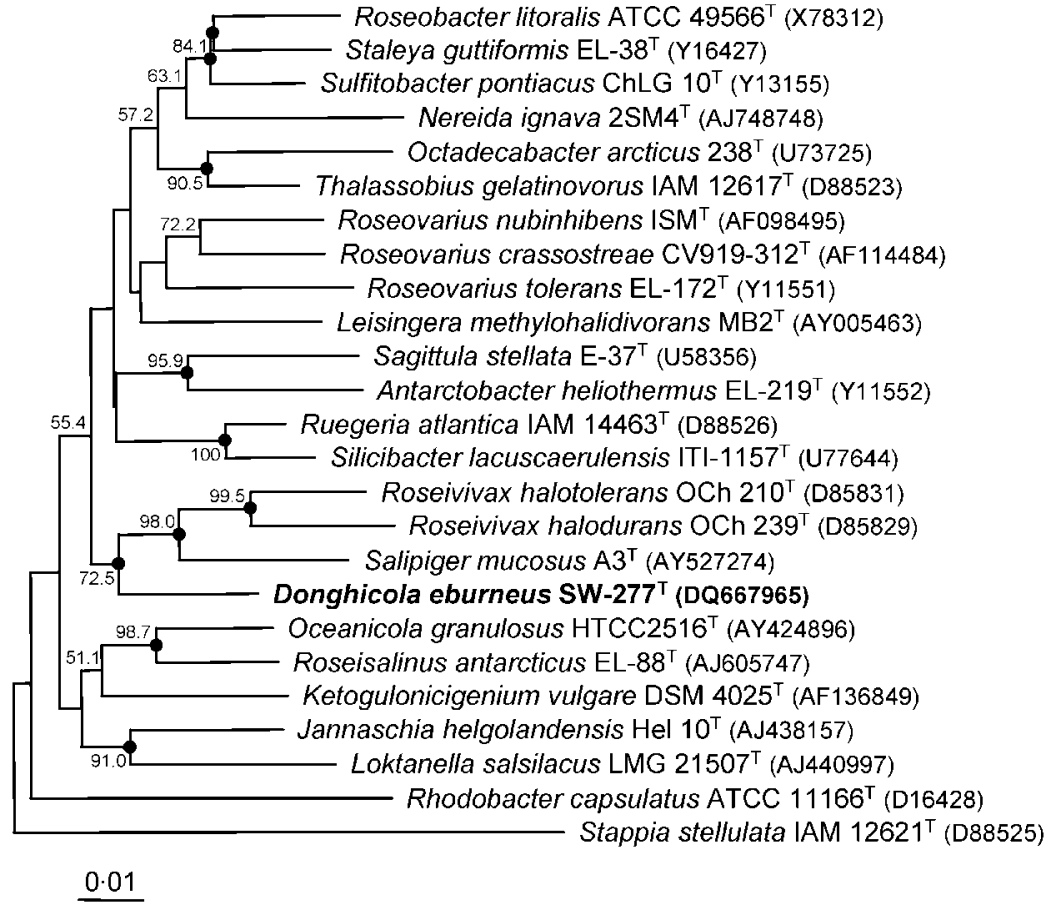

Fig. 1. Neighbour-joining phylogenetic tree based on 16S rRNA gene sequences showing the positions of Donghicola eburneus gen. nov., sp. nov. SW- $277^{\top}$ and some other related taxa. Bootstrap values (expressed as percentages of 1000 replications) of $>50 \%$ are shown at branch points. Stappia stellulata IAM $12621^{\top}$ was used as an outgroup. Bar, 0.01 substitutions per nucleotide position.
$94.6 \%$ to the type strain of S. mucosus and 93.8 and $94.7 \%$ to the type strains of Roseivivax halodurans and Roseivivax halotolerans, respectively. The fatty acid profile of strain SW $-277^{\mathrm{T}}$ comprised ( $>0.5 \%$ of total fatty acids): unsaturated fatty acids $\mathrm{C}_{18: 1} \omega 7 c(61.6 \%)$ and $\mathrm{C}_{18: 1} \omega 9 c(0.8 \%)$; straight-chain fatty acids $\mathrm{C}_{16: 0}(13.6 \%), \mathrm{C}_{18: 0}(9.2 \%)$, $\mathrm{C}_{14: 0}(1.4 \%)$ and $\mathrm{C}_{17: 0}(1.3 \%) ; 11-$ methyl fatty acid $\mathrm{C}_{18: 1} \omega 7 c(5.2 \%)$; hydroxy fatty acid $\mathrm{C}_{12: 1} 3-\mathrm{OH}(4.9 \%)$; and $\mathrm{C}_{16: 1} \omega 7 c$ and/or iso- $\mathrm{C}_{15: 0} 2-\mathrm{OH}(0.9 \%)$. The predominant respiratory lipoquinone detected in strain SW-277 ${ }^{\mathrm{T}}$ was ubiquinone-10 (Q-10) at a peak area ratio of approximately $94 \%$. The DNA G $+\mathrm{C}$ content of strain $\mathrm{SW}-277^{\mathrm{T}}$ was $59.7 \mathrm{~mol} \%$.

Phylogenetic analyses based on 16S rRNA gene sequences indicated that strain $\mathrm{SW}-277^{\mathrm{T}}$ did not fall within the radiation encompassed by a recognized genus, but forms an evolutionarily distinct lineage within the Alphaproteobacteria (Fig. 1). The predominant ubiquinone and fatty acid profile of strain $\mathrm{SW}-277^{\mathrm{T}}$ were similar to those of members of the phylogenetically related genera Salipiger and Roseivivax (Suzuki et al., 1999; Martínez-Cánovas et al., 2004). Members of many genera of the Alphaproteobacteria cannot be differentiated clearly by chemotaxonomic characteristics including major ubiquinone and fatty acid types (Nishimura et al., 1994; Martínez-Cánovas et al., 2004; Martens et al., 2006). Strain SW $-277^{\mathrm{T}}$ could be differentiated from members of the genera Salipiger and Roseivivax by differences in some phenotypic properties as listed in Table 1. Low 16S rRNA gene sequence similarity values between strain $\mathrm{SW}-277^{\mathrm{T}}$ and all other members of the Alphaproteobacteria, together with differential phenotypic properties, suggest that strain $\mathrm{SW}-277^{\mathrm{T}}$ represents a novel species in a new genus in the Alphaproteobacteria, for which the name Donghicola eburneus gen. nov., sp. nov. is proposed.

\section{Description of Donghicola gen. nov.}

Donghicola [Dong.hi'co.la. N.L. n. Donghae the Korean name of the East Sea in Korea; L. suff. -cola (from L. n. incola) a dweller, inhabitant; N.L. masc. n. Donghicola a dweller of the East Sea in Korea].

Cells are Gram-negative, aerobic, non-spore-forming cocci or rods. The predominant ubiquinone is Q-10. The major fatty acids are $\mathrm{C}_{18: 1} \omega 7 c$ and $\mathrm{C}_{16: 0}$. The type species is Donghicola eburneus.

\section{Description of Donghicola eburneus sp. nov.}

Donghicola eburneus (e.bur.ne' us. L. masc. adj. eburneus white as ivory).

Cells are Gram-negative, slightly halophilic, non-sporeforming cocci or rods $(0.6-0.8 \times 0.6-2.0 \mu \mathrm{m})$ existing singly, in pairs, in tetrads or long chains. Colonies on MA are circular to slightly irregular, slightly convex, smooth, ivory in colour and $2.5-3.5 \mathrm{~mm}$ in diameter after 3 days incubation at $37^{\circ} \mathrm{C}$. Growth occurs at 10 and $42{ }^{\circ} \mathrm{C}$, but not at 4 or $43^{\circ} \mathrm{C}$. Optimal pH for growth is between 7.0 and 8.0; growth occurs at $\mathrm{pH} 5.0$, but not at $\mathrm{pH}$ 4.5. Optimal growth occurs in the presence of $2 \%(\mathrm{w} / \mathrm{v}) \mathrm{NaCl}$. Growth occurs in the presence of $11 \%(\mathrm{w} / \mathrm{v}) \mathrm{NaCl}$, but not in the absence of $\mathrm{NaCl}$ or in the presence of more than $12 \%(\mathrm{w} / \mathrm{v}) \mathrm{NaCl}$. Anaerobic growth does not occur on MA or on MA supplemented with nitrate. Hypoxanthine and Tweens 20, 
40 and 60 are hydrolysed, but aesculin, casein, L-tyrosine and xanthine are not. $\mathrm{H}_{2} \mathrm{~S}$ is not produced. Arginine dihydrolase, lysine decarboxylase, ornithine decarboxylase and tryptophan deaminase are absent. L-Malate and pyruvate are utilized as carbon and energy sources, but maltose, sucrose, D-trehalose, D-xylose, benzoate, formate and salicin are not. Acid is produced from melibiose, but not from D-melezitose, D-raffinose, L-rhamnose, D-trehalose or myo-inositol. Susceptible to ampicillin, cephalothin, gentamicin, novobiocin, carbenicillin, kanamycin, neomycin and oleandomycin, but not to lincomycin. The major fatty acids ( $>10 \%$ of total fatty acids) are $\mathrm{C}_{18: 1} \omega 7 c(61.6 \%)$ and $\mathrm{C}_{16: 0}$ $(13.6 \%)$. Other phenotypic characteristics are given in Table 1.

The type strain is $\mathrm{SW}-277^{\mathrm{T}}\left(=\mathrm{KCTC} 12735^{\mathrm{T}}=\mathrm{JCM}\right.$ $13604^{\mathrm{T}}$ ), isolated from a seawater sample of Jungdongjin, the East Sea, Korea. The DNA G + C content of strain $\mathrm{SW}-277^{\mathrm{T}}$ is $59.7 \mathrm{~mol} \%$ (determined by HPLC).

\section{Acknowledgements}

This work was supported by the 21C Frontier program of Microbial Genomics and Applications (grant MG05-0401-2-0) from the Ministry of Science and Technology (MOST) of the Republic of Korea. We are grateful to Dr Jean Euzéby and Professor Hans Trüper for help with nomenclature of the novel genus and species.

\section{References}

Baumann, P. \& Baumann, L. (1981). The marine Gram-negative eubacteria: genera Photobacterium, Beneckea, Alteromonas, Pseudomonas, and Alcaligenes. In The Prokaryotes, vol. 1, pp. 1302-1331. Edited by M. P. Starr, H. Stolp, H. G. Trüper, A. Balows \& H. G. Schlegel. Berlin: Springer.

Bruns, A., Rohde, M. \& Berthe-Corti, L. (2001). Muricauda ruestringensis gen. nov., sp. nov., a facultatively anaerobic, appendaged bacterium from German North Sea intertidal sediment. Int J Syst Evol Microbiol 51, 1997-2006.

Cohen-Bazire, G., Sistrom, W. R. \& Stanier, R. Y. (1957). Kinetic studies of pigment synthesis by nonsulfur purple bacteria. J Cell Comp Physiol 49, 25-68.

Cowan, S. T. \& Steel, K. J. (1965). Manual for the Identification of Medical Bacteria. London: Cambridge University Press.

Komagata, K. \& Suzuki, K. I. (1987). Lipid and cell-wall analysis in bacterial systematics. Methods Microbiol 19, 161-206.

Lanyi, B. (1987). Classical and rapid identification methods for medically important bacteria. Methods Microbiol 19, 1-67.

Leifson, E. (1963). Determination of carbohydrate metabolism of marine bacteria. J Bacteriol 85, 1183-1184.

Martens, T., Heidorn, T., Pukall, R., Simon, M., Tindall, B. J. \& Brinkhoff, T. (2006). Reclassification of Roseobacter gallaeciensis Ruiz-Ponte et al. 1998 as Phaeobacter gallaeciensis gen. nov., comb. nov., description of Phaeobacter inhibens sp. nov., reclassification of
Ruegeria algicola (Lafay et al. 1995) Uchino et al. 1998 as Marinovum algicola gen. nov., comb. nov., and emended descriptions of the genera Roseobacter, Ruegeria and Leisingera. Int J Syst Evol Microbiol 56, 1293-1304.

Martínez-Cánovas, M. J., Quesada, E., Martínez-Checa, F., del Moral, A. \& Béjar, V. (2004). Salipiger mucescens gen. nov., sp. nov., a moderately halophilic, exopolysaccharide-producing bacterium isolated from hypersaline soil, belonging to the $\alpha$-Proteobacteria. Int J Syst Evol Microbiol 54, 1735-1740.

Nishimura, Y., Muroga, Y., Saito, S., Shiba, T., Takamiya, K. \& Shioi, Y. (1994). DNA relatedness and chemotaxonomic feature of aerobic bacteriochlorophyll-containing bacteria isolated from coasts of Australia. J Gen Appl Microbiol 40, 287-296.

Sasser, M. (1990). Identification of bacteria by gas chromatography of cellular fatty acids. Technical Note 101. Newark, DE: MIDI.

Staley, J. T. (1968). Prosthecomicrobium and Ancalomicrobium: new prosthecate freshwater bacteria. J Bacteriol 95, 1921-1942.

Suzuki, T., Muroga, Y., Takahama, M. \& Nishimura, Y. (1999). Roseivivax halodurans gen. nov., sp. nov. and Roseivivax halotolerans sp. nov., aerobic bacteriochlorophyll-containing bacteria isolated from a saline lake. Int J Syst Bacteriol 49, 629-634.

Tamaoka, J. \& Komagata, K. (1984). Determination of DNA base composition by reversed-phase high-performance liquid chromatography. FEMS Microbiol Lett 25, 125-128.

Yoon, J.-H., Kim, H., Kim, S.-B., Kim, H.-J., Kim, W. Y., Lee, S. T., Goodfellow, M. \& Park, Y.-H. (1996). Identification of Saccharomonospora strains by the use of genomic DNA fragments and rRNA gene probes. Int J Syst Bacteriol 46, 502-505.

Yoon, J.-H., Lee, S. T. \& Park, Y.-H. (1998). Inter- and intraspecific phylogenetic analysis of the genus Nocardioides and related taxa based on 16S rRNA gene sequences. Int J Syst Bacteriol 48, 187-194.

Yoon, J.-H., Kang, K. H. \& Park, Y.-H. (2003a). Psychrobacter jeotgali sp. nov., isolated from jeotgal, a traditional Korean fermented seafood. Int J Syst Evol Microbiol 53, 449-454.

Yoon, J.-H., Kang, K. H. \& Park, Y.-H. (2003b). Halobacillus salinus sp. nov., isolated from a salt lake on the coast of the East Sea in Korea. Int J Syst Evol Microbiol 53, 687-693.

Yoon, J.-H., Kim, I.-G., Kang, K. H., Oh, T.-K. \& Park, Y.-H. (2004a). Bacillus hwajinpoensis sp. nov. and an unnamed Bacillus genomospecies, novel members of Bacillus rRNA group 6 isolated from sea water of the East Sea and the Yellow Sea in Korea. Int J Syst Evol Microbiol 54, 803-808.

Yoon, J.-H., Yeo, S.-H. \& Oh, T.-K. (2004b). Hongiella marincola sp. nov., isolated from sea water of the East Sea in Korea. Int J Syst Evol Microbiol 54, 1845-1848.

Yoon, J.-H., Lee, M.-H. \& Oh, T.-K. (2004c). Porphyrobacter donghaensis sp. nov., isolated from sea water of the East Sea in Korea. Int J Syst Evol Microbiol 54, 2231-2235.

Yurkov, V., Stackebrandt, E., Holmes, A., Fuerst, J. A., Hugenholtz, P., Golecki, J., Gad'on, N., Gorlenko, V. M., Kompantseva, E. I. \& Drews, G. (1994). Phylogenetic positions of novel aerobic, bacteriochlorophyll a-containing bacteria and description of Roseococcus thiosulfatophilus gen. nov., sp. nov., Erythromicrobium ramosum gen. nov., sp. nov., and Erythrobacter litoralis sp. nov. Int J Syst Bacteriol 44, 427-434. 